Показані переваги використання транспортними засобами газових моторних палив, зокрема, зрідженого нафтового газу, у порівнянні з традиційним дизельним паливом. Обгрунтована доцільність конвертування дизелів транспортних засобів у газові двигуни внутрішнього згоряння із іскровим запалюванням.

Проведено аналіз способів зменшення ступеня стиснення дизелів при ї конвертації у газові двигуни внутрішнього згоряння з іскровим запалюванням. Показано, що для конвертацї̈ дизелів у газові двигуни внутрішнього згоряння з іскровим запалюванням доцільно використовувати термодинамічний цикл Отто зі зменшенням геометричного ступеня стиснення. Проаналізовані способи збільшення об'єму камери згоряння, а також доцільність застосування кожного з них для зменшення ступеня стиснення дизелів з різними типами нерозділених камер згоряння.

Обгрунтовано вибір і розроблено відкриту камеру згоряння у формі перевернутого осесимметричного «усіченого конусу», яка дозволила зменшити геометричну ступень стиснення лише за рахунок збільшення об'єму камери згоряння у поршні. Розроблена форма камери згоряння дозволяє використовувати та доопращювати итатні дизельні порині замість виготовлення спеціальних нових газових поринів.

Розроблено та створено газовий Әвигун внутрішнъого згоряння моделі Д-240-LPG з подачею зрідженого нафтового газу до впускного трубопроводу. Двигун обладнано безконтактною електронною системою запалювання з рухомим розподільником напруги, а також з поринями, що мають нову розроблену форму камери згоряння. Двигун конвертовано на базі дизеля Д-240.

Стендові випробування газового двигуна моделі Д-240-LPG nідтвердили доцільність конвертації дизелів у газові двигуни внутрішнъого згоряння з використанням циклу Отто. Випробування показали, що енергетичні та економічні параметри газового двигуна з запропонованою формою камери згоряння відповідають параметрам сучасних двигунів внутрішнъого згоряння з іскровим запалюванням.

Одержані результати дозволяють оптимізувати технологію переобладнання дизелів у газові ДВЗ і змениити ї̈ собівартість

Ключові слова: газові двигуни внутрішнього згорання, форма камери згоряння, зріджений нафтовий газ

$\square$

$\square$

DESIGNING THE SHAPE OF THE COMBUSTION CHAMBERS FOR GAS ENGINES CONVERTED ON THE BASIS OF THE DIESEL ENGINES

\title{
S. Kovalov
}

$\mathrm{PhD}$, Senior Researcher Research Laboratory of Fuels and Ecology State Enterprise «State Road Transport Research Institute»

Peremohy ave., 57, Kyiv, Ukraine, 03113 E-mail: skovalev@insat.org.ua

\section{Introduction}

The vehicles (hereinafter, Vs) that operate on conventional liquid motor fuels have contributed to the critical pollution of the environment. Therefore, over the past decade, the need has emerged for using more environmentally friendly types of fuels, which primarily include gas motor fuels.

Modern wheeled vehicles (hereinafter, WVs), especially buses and trucks and tractors, as well as municipal and agricultural machinery, are mostly equipped with the diesel engines having high operating costs of the diesel fuel. Thus, it is expedient to replace it with the most widespread and ecologically clean gas motor fuel - liquefied petroleum gas (hereinafter, LPG) [1, 2].

Thus, the most effective way to increase the use of LPG as a motor fuel is to convert the diesel engines of Vs into gas ICE with spark ignition. Such operations are appropriate and possible for both new Vs and those already in operation.

The main advantages of this re-equipment are the $100 \%$ replacement of the diesel fuel with cheaper LPG and the reduction of harmful emissions in the exhaust gases [2,3]. That also helps reduce the outside noise, preserve energy parame- ters of gas ICE at the level of $80 \ldots 100 \%$ of a standard diesel engine, as well as improve the engine motor resource, etc.

In addition, the benefits of using LPG also include the fact that it is stored aboard the Vs under small pressure (up to $1.6 \mathrm{MPa}$ ) in relatively light gas cylinders. In this case, in contrast to the compressed natural gas, LPG has a volumetric energy density close to gasoline and diesel fuels.

Conversion (re-equipment) of the $\mathrm{Vs}$ diesel engine to gas ICE with spark-ignition requires both complete dismantling of the power supply and diesel fuel injection systems and partial disassembly and introduction of the corresponding changes to the structure of ICE.

The main changes in the design of ICE include a set of operations aimed at reducing the degree of compression of the diesel engine in order to ensure its no-detonation work due to the relatively low values of the LPG octane numbers.

Thus, reducing the ratio of compression is one of the most complex and laborious operations that significantly influences both the time and cost of the Vs diesel engines conversion into gas ICE.

Given that the average retail price of LPG in recent years has amounted to $40 . .45 \%$ of the price of the diesel fuel, 
conversion of the diesel engines into gas ICE is an effective way to reduce operating costs of diesel-based Vs. In addition, the use of LPG as a motor fuel for Vs makes it possible to increase the share of alternative types of gas motor fuels in the total volume of motor fuels.

\section{Literature review and problem statement}

Paper [4] reports the results of studying a gas ICE converted on the basis of a serial 4-cylinder turbocharged diesel engine of the X17DTL model. The gas ICE was converted to operate on LPG with the Otto thermodynamic cycle [5]. The geometric degree of compression of the diesel engine from 22 to 13.1 was reduced in the simplest way - by adding two additional gaskets to a cylinder unit head. However, this technique leads to a significant deterioration of the environmental parameters of the converted ICE, and does not make it possible to reduce the compression degree to the values required to make the LPG-based engine operate without detonation. In addition, the presence of three gaskets in the cylinder unit head significantly reduces the ICE reliability.

The results of a study into the re-equipment of the tractor diesel engine D-240 to the gas ICE with forced ignition to operate on compressed natural gas were reported in paper [6]. The geometric compression degree of the diesel engine was reduced from 16 to 12 in the same way as it was reported in [4]. The disadvantages of the cited work are similar to flaws in [4].

In addition, the disadvantage of the converted gas ICEs $[4,6]$ is the absence of a «mechanism» (controller) to limit the maximum frequency rotation of a gas ICE, which can lead to its destruction when operated under the modes of forced idling.

Another technique to reduce the compression level is to use a Miller thermo-dynamic cycle [7], which provides a decrease not in the geometric but actual compression degree. In a Miller-cycle-based ICE, a tact of compression is conditionally reduced, but not decreasing by time but by the degree of compression of a working mixture. That is, the working mixture of such ICE is compressed less than that in a Millercycle-based ICE, which has the same geometric dimensions.

Study [8] analyzed a possibility to increase the efficiency of a 6-cylinder turbocharged gas ICE by increasing the geometric degree of compression co MPared to using a Miller cycle. The gas ICE, designed to operate on natural gas, had a capacity of $338 \mathrm{~kW} \cdot \mathrm{h}$ at a $1,900 \mathrm{~min}^{-1}$ rotation frequency, it was equipped with an open combustion chamber with a volumetric mixture formation; its compression degree equaled 11. It was shown in the cited study that the increase in the geometric compression degree from 11 to 12 and 13 could be achieved by reducing a combustion chamber volume in the piston, reducing the diameter and height of the combustion chamber. Next, the results of the calculation of the gas ICE parameters that used the Miller cycle were analyzed. The calculations were conducted for three angles of the earlier closing of the inlet valve and for three angles of the later closing of the inlet valve. Based on the optimal result of the calculations, the authors changed the structure of the gas ICE. Their experimental study of the gas ICE showed that when closing the inlet valve 40 degrees earlier, the compression degree increases up to 13 units, and the maximum thermal efficiency reaches $47 \%$. However, the authors disregarded the fact that an increase in the thermal efficiency of the Miller cycle relative to the Otto cycle is acco MPanied by the loss of torque (capacity) of ICE because of the deterioration of cylinder filling.

Paper [9] considered two ways to reduce the degree of the diesel engine compression when converting it to a gas ICE. A first technique implied that the geometric compression degree of the diesel engine decreased by introducing additional gaskets for the cylinder unit head. The result was the decrease in the compression degree, similar to [4], reduced to 13.1. According to a second technique, a reduction in the compression degree was achieved by using a Miller cycle through the later closing, by 22.5 degrees, of the inlet valve. That allowed the authors to reduce the compression degree to 13.2. However, they did not answer how it was possible to avoid the no-detonation work of the engine on LPG at such a high degree of compression.

A possibility to improve the efficiency of gas engines (reequipped based on diesel engines) by using the Miller cycle was considered in article [10]. The possibility of a higher fuel economy was shown when utilizing stochiometric mixtures and at the same time geometric compression degree as that in the diesel engine. To further reduce the toxicity of exhaust gases and to ensure operation on lean mixtures, it is recommended to use a new, more complex and costlier, system of selective catalytic treatment.

Article [11], which is a continuation of work [10], analyzed and compared the complexity and cost of the systems for neutralizing the exhaust gases from the diesel engines, as well as from petrol and gas ICEs. It was shown that for these engines to meet the pollutant emission norms within Euro 4 to Euro 6, the complexity and cost of treatment systems substantially increases. In this case, the complexity and cost of the gas ICE cleaning systems to comply with the norms within Euro 4 to Euro 6 do increase but less than those in the diesel engines.

Thus, the conversion of the diesel engines into gas ICEs with the application of a Miller cycle makes it possible to solve only the issue that concerns the reduction of compression degree without changing the design of a combustion chamber. However, the diesel engine combustion chamber is designed for the organization and efficient progress of the working process exclusively on diesel fuel. In order to ensure the energy-efficient combustion process of gas fuels, in particular LPG, the engine must have the shape of the combustion chamber that differs from that in the diesel engine. However, it should be noted that the conversion of the diesel engines into gas ICEs using a Miller cycle (without changing the combustion chamber shape) does not address the main problem of ensuring energy-efficient and environmentally friendly operation of the gas ICE.

In turn, when converting the diesel engines to gas ICE to be operated using an Otto cycle the reduction of the geometric degree of compression is achieved by increasing the volume of the combustion chamber. In this case, a new shape of the chamber makes it possible to resolve the task of providing energy-efficient and environmentally friendly operation of the LPG-based gas ICE.

At present, the world engine engineering is dominated by the production of engines with the unpartitioned combustion chambers located in the piston. Thus, hereafter, in order to convert the diesel engines to gas ICEs to be operated using an Otto cycle, such a change in the shape of the combustion chamber will be considered that relates only to such combustion chambers. 
The main types of the non-divided combustion chambers, which are most common in the automotive and tractor diesel engines, are shown in Fig. 1. These include combustion chambers that enable: a volumetric-film mixture formation (Fig. 1, $a$ ), a volumetric mixture formation (Fig. 1, $b$ ), and film mixture formation or the M-process (Fig. 1,c) [12-14].

The compression degree in the non-divided combustion chambers shown in Fig. 1 can be reduced by the following five techniques:

1) increasing only the volume of the combustion chamber located in the piston;

2) using pistons with a reduced distance from the axis of the piston finger to the bottom of the piston;

3 ) increasing only the volume of the combustion chamber located in the cylinder unit head;

4) both by a partial increase in the volume of the combustion chamber in the piston and a partial increase in the volume of the combustion chamber in the cylinder unit head;

5 ) both by a partial increase in the volume of the combustion chamber in the piston and by installing an additional pre-chamber located in the cylinder unit head.

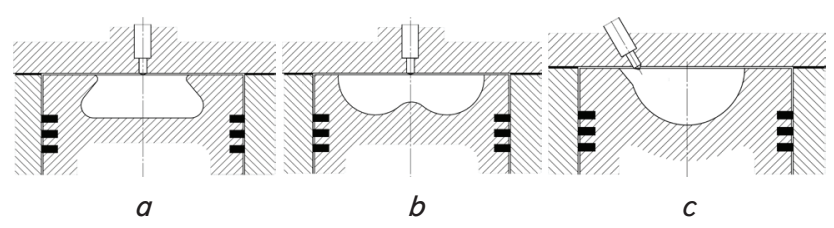

Fig. 1. Types of the diesel engine non-divided combustion chambers: $a$-combustion chamber that enables a volumetric-film mixture formation; $b$ - combustion chamber that enables a volumetric mixture formation; $c$ - combustion chamber that enables a film mixture formation

A first technique is advisable when converting the diesel engines, which have the shapes of combustion chambers that enable a volumetric mixture formation (Fig. 1, $a$ ), a volumetric mixture formation (Fig. 1, $b$ ), and a film mixture formation (Fig. 1,c). Increasing the volume of the combustion chamber is achieved changing the shape of its design, that is, by increasing the volume of the combustion chamber located in the piston. The advantages of this technique include making significant changes in the design of only one ICE component, the piston, as well as the possibility of simple improvement of standard diesel engine pistons, instead of fabricating new pistons involving specialized costly casting equipment.

A second technique is advisable when converting the diesel engines, which enable a volumetric mixture formation and have a relatively small depth of the combustion chamber (to the bottom). For such combustion chambers, increasing their volume can be achieved by using new pistons with a reduced distance from the axis of the piston finger to the piston bottom. In this case, if possible, it is advisable to change the shape of the combustion chamber design as well.

A third technique is advisable when converting the diesel engines, which also enable a volumetric mixture formation (Fig. 1, $a$ ). Increasing the volume of the combustion chamber can be achieved by increasing the volume only, which is in the cylinder unit head in a spark plug zone. This technique requires the manufacture of a new cylinder unit head and, consequently, a significant increase in the labor intensity of the conversion.
A fourth technique is also advisable in converting the diesel engines, which enable the volumetric, film, and volumetric-film mixture formation (Fig. 1, $a, b$ ). Using this technique requires both a partial increase in the volume of the combustion chamber in the piston and a partial increase in the combustion chamber in the cylinder unit head in a spark plug zone. However, this technique, in terms of making changes in the cylinder unit head, has the same flaws as the third technique.

A fifth method is also advisable when converting the diesel engines, which enable a volumetric-film mixture formation (Fig. 1, $a$ ) or a film mixture formation (Fig. 1, $b$ ). This technique requires both a partial increase in the volume of the combustion chamber in the piston and a partial increase in the volume of the combustion chamber in the cylinder unit head. In this case, the increase in the combustion chamber in the cylinder unit head is achieved by installing an additional pre-chamber whose channel host a diesel injector. The advantages of this technique include the fact that the installation of spark plugs does not require the creation of a special additional channel in the head of the cylinder unit: it is installed to an additional pre-chamber. In contrast to the third and fourth techniques, the fifth technique, despite a slight increase in the labor intensity of the conversion, can also be used to convert the diesel engines that are in operation.

Thus, in order to convert the diesel engines into gas ICEs with spark ignition, it is advisable to use a thermodynamic Otto cycle with a decrease in the geometric degree of compression by increasing a combustion chamber volume in the piston. Such a technique makes it possible to use standard diesel pistons and to install the spark plugs in the modified channel of the cylinder unit head instead of dismantled diesel nozzles.

\section{The aim and objectives of the study}

The aim of this study is to substantiate the choice and to design a shape of the combustion chamber of gas ICEs operated on LPG, converted on the basis of standard diesel engines, which are in operation, in order to ensure their nodetonation, energy-efficient, and economical performance.

To accomplish the aim, the following tasks have been set:

- to design a shape of the combustion chamber, which makes it possible to reduce the geometric degree of engine compression to the value that ensures its no-detonation, energy-efficient, and economical operation on LPG;

- to fabricate (on the basis of regular pistons for the diesel engine D-240) pistons for gas ICE with the designed shape of the combustion chamber;

- to design and fabricate a special electronic control unit (hereinafter, ECU), limiting the maximum rotation frequency of a gas ICE;

- to convert the transportation diesel engine D-240 into a gas ICE operated on LPG with installing the pistons with the designed shape of the combustion chamber;

- to carry out bench testing of the gas ICE, model D-240-LPG, in order to determine its energy and economic indicators.

\section{Basic requirements for the shape of the combustion chamber of gas ICEs operating on LPG}

The combustion chamber shape of the gas ICE with spark ignition must ensure the required compression ratio for the 
combustion of LPG and the minimal heat losses through the surface of the combustion chamber, that is, the minimum surface area of the combustion chamber [14].

In addition, the shape of the combustion chamber should be such that its manufacture could employ standard diesel pistons, and their modification should be made possible using regular technological equipment (lathes) for the machining of parts.

The degree of compression of a gas ICE, which should operate on LPG, is selected taking into consideration the octane number of the LPG. In its turn, the LPG octane number depends on its grade [15], which is defined by the amount of propane and butane included in its formulation. For different brands, it slightly exceeds the octane number of conventional gasoline. Given this, the degree of compression of a gas ICE operating on LPG should be chosen within the compression degrees for gasoline ICEs, that is, $9.0 \div 10.5$.

\section{The shape of the combustion chamber of the gas ICE operating on LPG, manufactured on the basis of standard pistons for the diesel engines of models D-240}

Consider the shape formation of a combustion chamber using the piston of the gas ICE, model D-240-LPG, converted on the basis of the diesel engine D-240, as an example.

Fig. 2, $a, b$ shows the photographs of a standard piston (catalog number 240-1004021-A) for the diesel engines of models D-240, produced by PP «Zavod Dvigatel» (Ukraine, Melitopol) [16]. The pistons are manufactured separately or included in the kit «Piston MTZ «DAL'NOBOYSHCHIK» D-240» (hereinafter, the piston set D-240). The compression ratio of the diesel engine D-240 with such pistons equals $\varepsilon=16$.

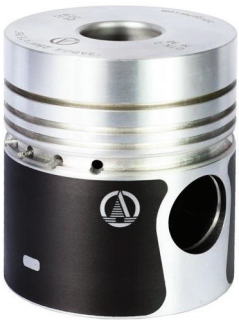

a

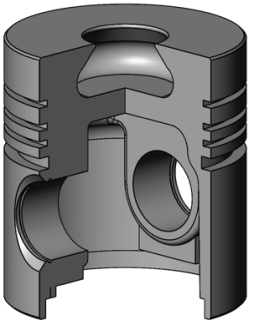

$b$

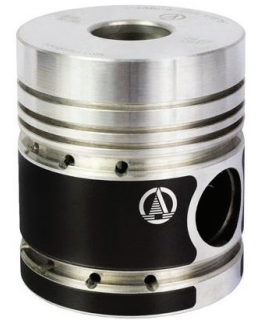

c
Fig. 2. Design of a standard piston for the diesel engine D-240 with the combustion chamber CNIDI: $a, b-$ piston with a single groove for an oil scraper ring; $c$ - piston with two grooves for oil scraper rings

Geometric dimensions of the piston: bore $-110 \mathrm{~mm}$, stroke $-125 \mathrm{~mm}$, the diameter of the combustion chamber opening $-38.0 \mathrm{~mm}$, the diameter of the combustion chamber $-62.1 \mathrm{~mm}$, the depth (to bottom) $-27^{-0.18} \mathrm{~mm}$, the transition radius from the lateral wall to the chamber's bottom $-8.0 \mathrm{~mm}$. The ratio of the diameter of the combustion chamber to the cylinder diameter is $d_{c c} / D=0.56(45)$.

The pistons are equipped with the CNIDI combustion chamber, which enables a volumetric mixture formation. The pistons are executed in two versions: with 3 grooves for compression rings and a single (Fig. 2, $a$ ) or two grooves (Fig. 2, $b$ ) for oil scraper rings.

The piston is made from the high-strength aluminum alloy AK12M2MgN, with an antifriction coating applied onto the working surface.
It is obvious that the diesel engine chamber CNIDI and other shapes of non-separated combustion chambers of the diesel engines do not meet the requirements for the gas ICE combustion chambers, in which gaseous fuel is fed or injected to the inlet pipeline. In this case, it should be taken into consideration that the gas ICE compression degree is significantly less than that in the diesel engines.

In other words, in contrast to the diesel engine, which has internal mixture formation and, as a consequence, limited time for the formation of a homogeneous fuel-air mixture, the gas ICE has an external mixture formation, at which the time needed for the formation of a homogeneous gas-air mixture increases. Moreover, after the evaporation in a gas reducer-evaporator, LPG is supplied through the gas-air mixer to the inlet pipeline in a gaseous state. Consequently, in contrast to gasoline, gas fuel does not require time for evaporation.

As a result, the non-divided combustion chamber of a gas ICE may have a non-complicated shape to enable a volumetric mixture formation. Thus, in contrast to the shape of a combustion chamber for the diesel engine, the shape of the combustion chamber for a gas ICE can be simplified and it needs neither a turbulent edge nor a displacer.

Thus, to reduce the degree of compression of the diesel engine $(\varepsilon=16)$, at its conversion into a gas ICE, it is necessary to increase the volume of the combustion chamber (for example, a CNIDI chamber) by almost 2 times. This is only possible through a substantial increase in the volume of the diesel engine combustion chamber, by transforming the semiclosed CNIDI chamber into an open combustion chamber for which $d_{c c} / D=0.7-0.85$ [13]. To ensure the maximum homogenization of a gas-air mixture and to reduce the surface area of the combustion chamber, it is advisable to choose the combustion chamber shape in the form of an inverted axisymmetric «truncated cone».

In this case, its smaller base should have a diameter that is, accordingly, 1.0-1.2 of the diameter of the bottom of the CNIDI combustion chamber. A larger base that is directed towards the cylinder unit head must have a diameter that is, respectively, $0.8-0.85$ of the cylinder diameter. The height of the «truncated cone» should be 1.0-1.06 of the height of the CNIDI combustion chamber. The bottom of the combustion chamber must be paired to the lateral surface by a radius of $2.0-10.0 \mathrm{~mm}$. And the diametrical plane of the combustion chamber must be aligned to the side surface (from the greater base of the cone) by a radius of $1.0-4.0 \mathrm{~mm}$.

Fig. 3 shows a piston of the gas ICE D-240-LPG with an open combustion chamber whose shape corresponds to the inverted axisymmetric «truncated cone». The pistons were manufactured based on standard pistons (Fig. 2) for the diesel engine D-240, which are included in the kit «Piston MTZ «DAL'NOBOYSHCHIK» D-240».

By using such pistons, the compression degree of the gas ICE D-240-LPG was reduced to $\varepsilon=9.5$. The ratio of the diameter of the combustion chamber (greater base of the «truncated cone») to the diameter of the cylinder is $d_{c c} / D=0.818$, and of the smaller base of the diameter of the «truncated cone» bottom to the bottom of the CNIDI combustion chamber is, respectively, 1.04. The height of the «truncated cone» to the height of the CNIDI combustion chamber is, accordingly, 1.059. The combustion chamber bottom is connected to the lateral surface by a radius of $8 \mathrm{~mm}$, and the combustion chamber's diametrical plane is aligned to the side surface from the greater base of the cone by a radius of $1.0 \mathrm{~mm}$. 


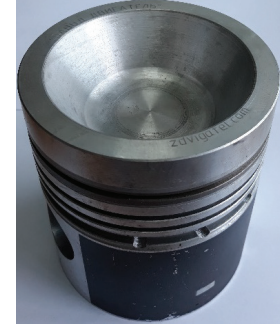

a

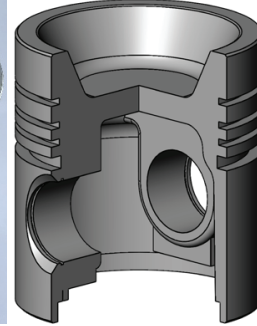

$b$

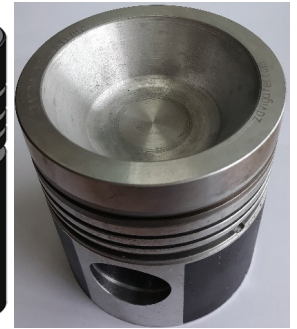

c

Fig. 3. A piston of the gas ICE D-240-LPG with a shape of the combustion chamber in the form of an inverted axisymmetric «truncated cone»: $a, c$ - photographs of the piston and combustion chamber; $b-a$ model of the piston cross-section

\section{Features of the re-equipment of the diesel engine D-240 into the gas ICE D-240-LPG operating on LPG}

The gas ICE, model D-240-LPG, has been converted, based on the diesel engine D-240, by carrying out its overhaul with the dismantling of the regular diesel fuel supply system. In the process of conversion, the engine design was modified by making such changes as the improvement of the cylinder unit head for the diesel engine in order to install the spark plugs, and, to reduce the degree of compression, by installing the new modified piston.

The cylinder unit head was modified in order to install the spark plugs by cutting the screw with $12 \times 1.25$ threads in the cylinder unit head ducts of the diesel engine D-240, intended to install the diesel nozzles.

Before that, the gas ICE D-240-LPG was supplemented with four sets «Piston MTZ «DAL'NOBOYSHCHIK» D-240» with new pistons (Fig. 3) with an open combustion chamber in the form of an inverted axisymmetric «truncated cone». The kit included a new piston, compression and oil scraper rings, a cylinder sleeve, a piston finger, retainer rings and sealing gaskets under the cylinder sleeve.

In addition, the converted gas ICE D-240-LPG was supplemented with a system to supply gas fuel (specifically, LPG) and a contactless electronic ignition system with a movable voltage distributor; the air supply system was changed, too.

The gas ICE power system includes the elements of specialized equipment, shown in Fig. 4. In this case, the gas-air mixer (Fig. $4, f$ ) is mounted onto the inlet pipe before the throttle valve.

All elements of the LPG supply system, installed on the gas ICE, model D-240-LPG, meet the requirements of the Regulation No. 67 [17].

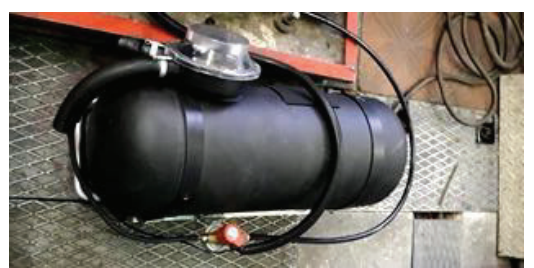

a

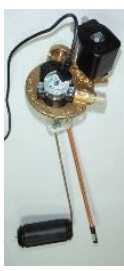

$b$

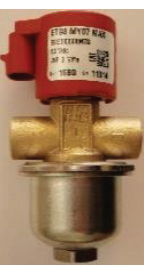

c

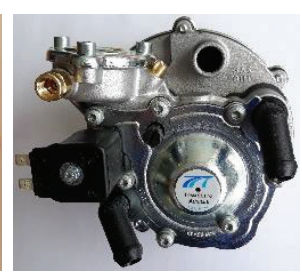

d
It should be noted that when converting the diesel engine D-240 into the gas ICE D-240-LPG, the diesel fuel equipment was dismantled along with a mechanical regulator of rotation frequency. As a result, the gas ICE with the LPG feed to the inlet pipeline remains without the «mechanism» (controller) that limits the maximum rotation frequency. That is, the absence of the controller leads to that, after the gas engine achieves the rated rotation frequency, given a possibility of the further growth of gas supply, the rotation frequency can increase, rather than decrease, as is the case when during operation based on the external regulatory characteristic of the diesel engine (dependence $N_{e, d}$ in Fig. 10,a). Thus, during a gas engine operation the maximum rotation frequency, set by a manufacturer for the corresponding diesel engine model, can be exceeded, which could lead to the destruction of the engine.

To avoid such an event, a special ECU Avenir Gaz was designed and manufactured, shown in Fig. 5. The ECU is built on the basis of an 8-bit microcontroller PIC16F (Microchip Technology Inc.) with a clock frequency of $20 \mathrm{MHz}$. The processing power (performance) of the microcontroller reaches 5 DMIPS.

The main purpose of ECU is to limit the maximum frequency of rotation by controlling the operation of shut-off valves (integrated into the multivalve, gas filter and reducerevaporator) of the LPG supply system (Fig. $4, b-d$ ).

The ECU Avenir Gaz operates in the following way. A signal from a Hall sensor, located in distributor 1 of the ignition system (Fig. 6), is sent to the terminal of its electronic switch and is duplicated and arrives at ECU. This signal, whose pulse frequency is proportional to the current rotation frequency of the crankshaft, is processed by ECU and compared to the pre-programmed magnitude of the maximum frequency. In the case when the magnitude of the current frequency of the engine rotation frequency reaches the magnitude of the pre-programmed maximum rotation frequency, ECU acquires a signal of $+12 \mathrm{~V}$ from the coil of the relay, arranged on the ECU board. As a result, the contacts of the relay open and the shut-off electromagnetic valves (integrated into the multivalve, gas filter and reducer-evaporator, Fig. $4, b-d$ ) are closed. In this case, the supply of LPG from a gas cylinder to the mechanical gas dispenser and the gas-air mixer is terminated.

As a result, the engine, due to inertia, continues to rotate, but the crankshaft rotation frequency (in the absence of LPG supply) decreases and, after its reduction (by the magnitude of the pre-programmed hysteresis), ECU sends to the coil of the relay a signal of $+12 \mathrm{~V}$. The relay contacts close and the shut-off electromagnetic valves (integrated into the multivalve, gas filter, and evaporator reducer) are opened again. LPG from a gas cylinder is fed back to the air mixer again. The engine starts but operates at a lower crankshaft rotation frequency (dependence $N_{e, g}$ in Fig. 10, $a$ ).

Fig. 4. Basic elements in the gas supply system for the gas ICE D-240-LPG:

$a$ - gas cylinder for LPG; $b$ - multivalve with an integrated remotely controlled shut-off valve and a sensor-indicator of LPG level; $c$ - gas filter with remotely operated shut-off valve; $d$ - two-step gas reducer-evaporator with an integrated remotely controlled shut-off valve; $e-$ mechanical dispenser of gas; $f$ - gas mixer 


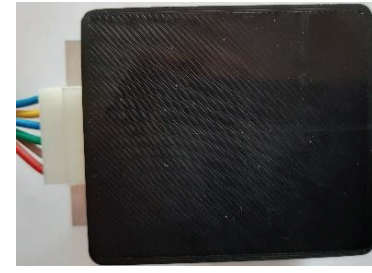

$a$

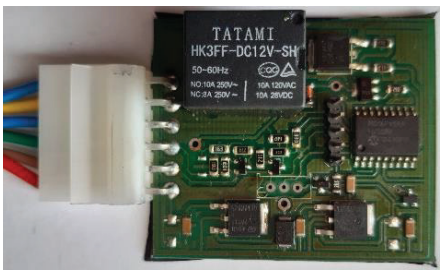

b
Fig. 5. ECU Avenir Gaz: $a$ - physical appearance; $b$ - physical appearance of the ECU board

In addition, ECU sends via the relay contacts a signal of $+12 \mathrm{~V}$ to the shut-off electromagnetic valves (integrated into the multivalve, gas filter and reducer-evaporator) only at the beginning of the launch of the gas engine. Thus, ECU makes it impossible to supply LPG to the gas-air mixer and the inlet pipeline before the start of the gas engine, which improves the safety of its operation.

Note that the converted ICE is supplemented with a gas fuel supply system (specifically, LPG) and a contactless electronic ignition system with a movable voltage distributor; the changes were made to the air supply system, too.

Another system that the gas ICE D-240-LPG was supplemented with is a contactless electronic ignition system with a movable voltage distributor (hereinafter, CEIS). The gas ICE D-240-LPG was equipped with CEIS, which is used for 4-cylinder gasoline ICEs. The system includes an electronic switch; a voltage distributor; a coil of high voltage; high-voltage wires and spark plugs. One of the most important elements of the circuit is a photovoltaic Hall sensor, built into the voltage distributor. Owing to it, the electronic switch captures the position of the gas ICE distribution shaft and determines the moment of spark formation at a sequence of (1-3-4-2).

The main elements of CEIS and their arrangement on the gas ICE D-240-LPG are shown in Fig. 6.

To install the distributor on the gas engine, a special mechanical drive was designed and manufactured, set into action from the ICE gear unit. The distributor in an assembly with a special mechanical drive are installed and fixed in place of the dismantled standard high-pressure fuel pump UTN-5.

The ignition coil and four spark plugs are connected to the distributor using the kit TESLA TZ T135H of 5 high-voltage ignition wires with a resistive core and multilayer insulation.

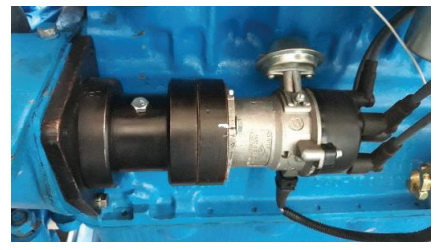

a

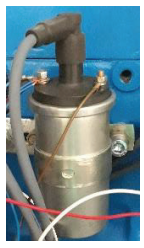

b

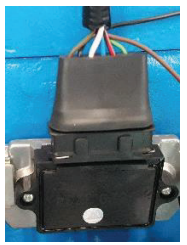

c

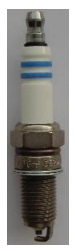

d
Fig. 6. Basic elements of CEIS: $a$ - special drive of the distributor with assembled distributor; $b$ - ignition coil; $c$ - electronic switch; $d-$ spark plug

The third system, which was added to the gas ICE D-240-LPG, is a system to fill the cylinders with a working mixture (Fig. 7).

The filling system includes an inlet pipeline assembly (Fig. 7, $a$ ), a throttle flap with a mechanical drive (Fig. 7,b), an adapter (Fig. 7,c) between the throttle and inlet pipeline, and a gas mixer (Fig. 4, $f$ ).

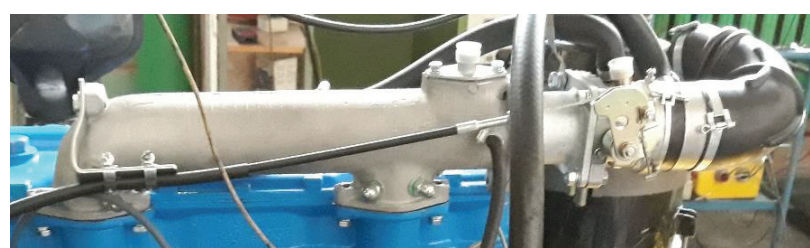

$a$

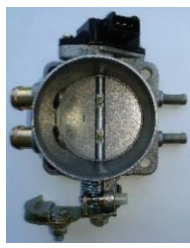

b

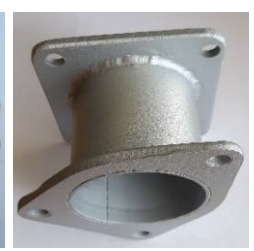

$c$
Fig. 7. Main elements of the system to fill cylinders with a working mixture: $a-$ inlet pipeline (assembled), installed on D-240-LPG; $b$ - throttle flap; $c$ - adapter

7. Results of experimental study of the gas ICE D-240-LPG with pistons with the designed shape of the combustion chamber

The energy and economic indicators of the converted gas ICE, model D-240-LPG, were determined during bench testing at an electric loading bench Zöllner (Germany), type B-350AC, with a modernized microprocessor system of measurement and control (Fig. 8). The bench can measure torque in ranges from 0 to $199 \mathrm{~N} \cdot \mathrm{m}$ and from 200 to $2,000 \mathrm{~N} \cdot \mathrm{m}$, as well as an engine rotation frequency from 100 to $6,500 \mathrm{~min}^{-1}$.

The consumption of LPG was measured by the Coriolis-type fuel flowmeter FlexCOR CMF-BEQ0B1AWCJ2100A (Fig. 9, $a, b$ ). It operates in the ranges from 0.3 to $12 \mathrm{~kg} / \mathrm{h}$ and from 12 to $250 \mathrm{~kg} / \mathrm{h}$. Air consumption was measured by the air flowmeter GF-90-A1A00AD-AA00060DA5A4 (Fig. 9, $c, d$ ). It operates in the ranges from 8 to $64 \mathrm{~m}^{3} / \mathrm{h}$ and from 64 to $1,200 \mathrm{~m}^{3} / \mathrm{h}$ (both made in the USA by FCI). The coefficient of excessive air $\lambda$ was calculated by the standard program of the measuring module, the gas analyzer VEA 060 (Fig. 9,e) of the mobile complex BOSCH VEA 550.

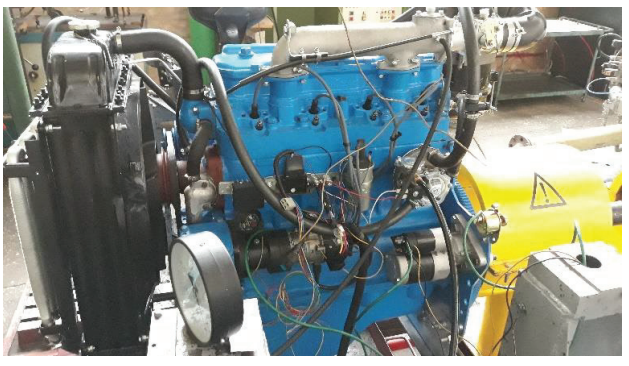

a

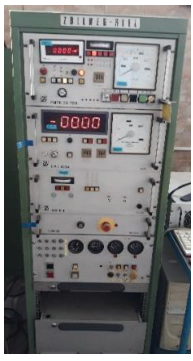

$b$
Fig. 8. Physical appearance of the converted gas ICE, model D-240-LPG, mounted at the Zöllner load bench: $a$ - gas ICE, model D-240-LPG; $b$ - Zöllner load bench control cabinet

In addition, in the course of tests, the modernized microprocessor measuring and bench control system registered such parameters as the atmospheric pressure and humidity of air in a testing cabinet; the temperature of inlet air, motor oil, coolant, and exhaust gases. 


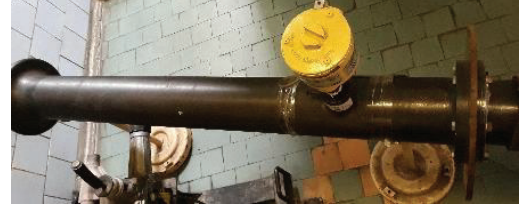

$a$

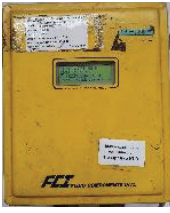

$b$



C

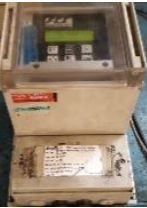

d

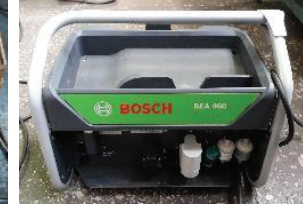

e

Fig. 9. The main measuring tools and testing equipment:

$a, b$ - mass air flow meter GF-90-A1A00AD-AA00060DA5A4; $c, d$-Coriolis-type fuel flowmeter FlexCOR (LPG); $e-$ module gas analyzer BEA 060 of the mobile complex BOSCH BEA 550

All the test equipment involved in the experimental study, were calibrated or attested, and the accuracy of all measurements was consistent with the requirements of GOST 18509 [18] and Regulation No. 120 [19].

Fig. 10, $a, b$ shows the external speed characteristic of the gas ICE D-240-LPG (solid lines), determined in the process of testing, as well as the external speed characteristic of the diesel engine D-240 (dashed lines).

It should be added that the basic parameters of the external speed characteristic of the diesel engine D-240 were derived from literary sources [20].

In addition, the tests of the gas ICE D-240-LPG involved LPG of the PBT grade, in line with GOST R 52087 [21], manufactured by OOO «Gazenergoset Bryansk» at Klintsovskaya GNS (Republic of Belarus).

According to the Passport of Quality No. 53 as of 21.04.2019, the LPG contains (by weight) $56.47 \%$ of propane and $40.79 \%$ of butane (i-butane $-18.67 \%$ and $n$-butane $-22.12 \%$ ). The density of this LPG at $10^{\circ} \mathrm{C}$ is $0.5347 \mathrm{~kg} / \mathrm{l}$.

Fig. 10, $a$ and Table 1 demonstrate that the rated power of the diesel engine D-240 is $N_{e, d}=59 \mathrm{~kW}(80 \mathrm{hp})$ at the rated crankshaft rotation frequency $n=2,200 \mathrm{~min}^{-1}$. The maximum effective torque is $M_{e . d}=305 \mathrm{~N} \cdot \mathrm{m}$, at $n=1,400 \mathrm{~min}^{-1}$. The torque margin is $19 \%$.

In turn, as shown in Fig. 10, $a$, and Table 1, the maximum capacity of the gas ICE D-240-LPG is $N_{e, g}=57.5 \mathrm{~kW}$ (78 hp) at the rated crankshaft rotation frequency $n=2,250 \mathrm{~min}^{-1}$. Thus, the rated (maximum) capacity of the gas ICE D-240-LPG was $97 \%$ of the rated capacity of the diesel engine D-240 (Table 1). The maximum effective torque is $M_{e, g}=304 \mathrm{~N} \cdot \mathrm{m}$, at $n=$ $=1,300 \mathrm{~min}^{-1}$. The characteristic of the effective torque smoothly increases with a decrease in the engine rotation frequency from rated to $n=1,300 \mathrm{~min}^{-1}$ and then decreases. The torque margin in the gas ICE is $22 \%$ (Table 1 ), which is $3 \%$ higher than the margin of the diesel engine torque.

Liter power, which assesses the efficiency of the use of the cylinder working volume, of the gas ICE is equal to $N_{l, g}=12.1 \mathrm{~kW} / \mathrm{l}$, while that of the diesel engine is slightly higher $N_{l, d}=12.4 \mathrm{~kW} / \mathrm{l}$.

Effective consumption of LPG in the operation of a gas ICE based on the external speed characteristic ranges from 4.0 to $11.3 \mathrm{~kg} / \mathrm{h}$ (or $7.5 . .21 .1 \mathrm{l} / \mathrm{h}$ ) at rotation frequency from 900 to $2,200 \mathrm{~min}^{-1}$, respectively.

The mean effective pressure $P_{e}$ of the gas engine (Fig. 10, $b$ ) varies in the range from $0.65 \mathrm{MPa}$ at $2,200 \mathrm{~min}^{-1}$ to $0.79 \mathrm{MPa}$ at $1,100 \ldots 1,200 \mathrm{~min}^{-1}$, which generally corresponds to the indicators for modern gas ICEs.

The coefficient of the gas ICE fuel cylinder filling ranges from 0.77 to 0.96 . In this case, the coefficient increases with the reduction in the engine rotation frequency, indicating the negative impact caused by the hydraulic resistance of the gas-air mixer (diffuser) on the magnitude of the coefficient at the rated and mean frequencies of rotation.
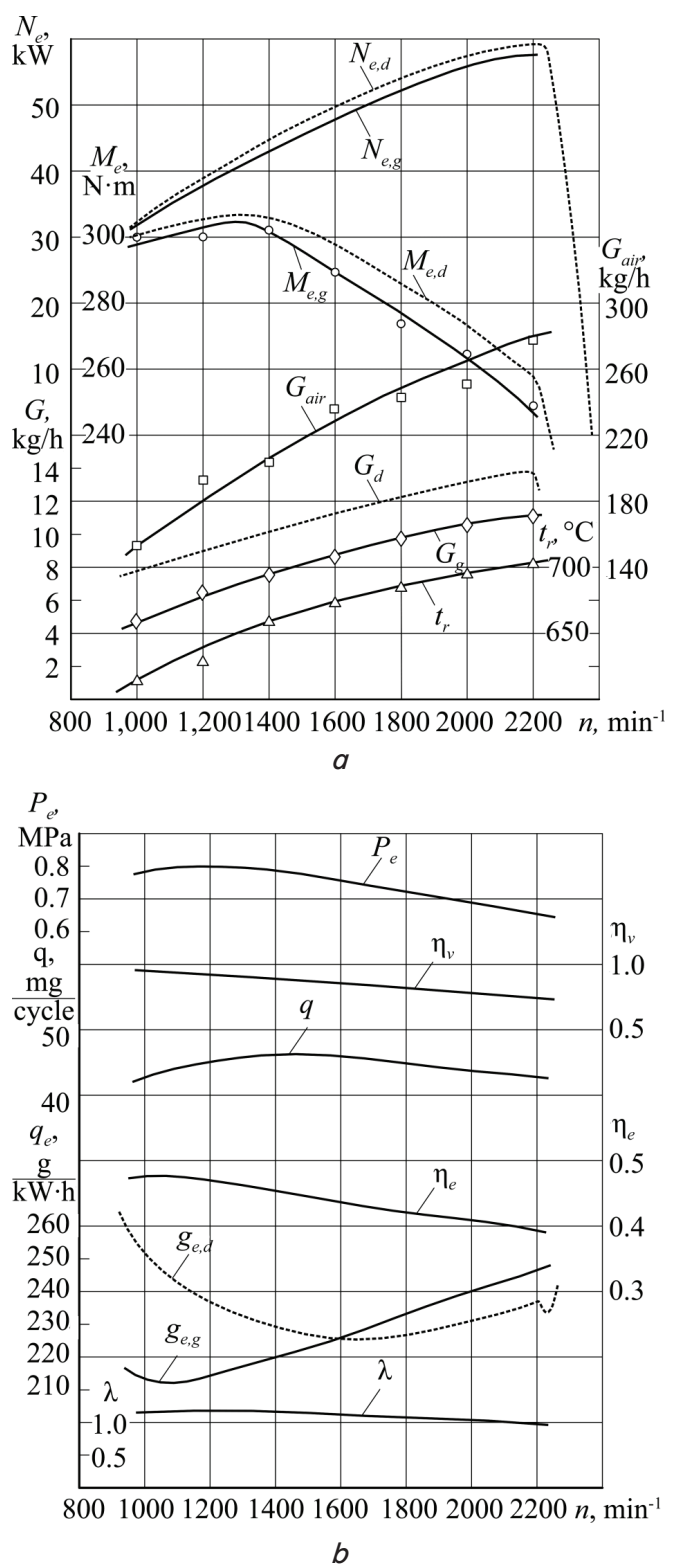

Fig. 10. External speed characteristic: $a$ - energy parameters; $b$ - economic parameters;

- gas ICE D-240-LPG; ----- - diesel engine D-240;

$N_{e}$ - effective power; $M_{e}-$ effective torque; $G_{\text {air }}-$ hourly air flow rate; $G$ - hourly fuel consumption; $t_{r}$ - temperature of exhaust gases; $P_{e}-$ mean effective pressure; $\eta_{v}-$ cylinder filling factor; $q$-cyclic supply gas; $\eta_{e}-$ effective efficiency; $g_{e}$ - specific effective fuel consumption; $\lambda$ - coefficient of excessive air; $n-$ the engine speed

The effective efficiency of the gas ICE $\eta_{e}$ is at the level of $0.39 \ldots 0.48$, which indicates a sufficiently high fuel efficiency 
of the gas ICE and the high degree of utilizing the heat from the combustion of gas fuel.

In this case, effective specific consumption of LPG (Fig. 10, $b$ ) when operated at rated capacity amounted to $g_{e, g}=197 \mathrm{~g} /(\mathrm{kW} \cdot \mathrm{h})$. The minimum effective specific consumption of LPG corresponds to $n_{d}=1,050 \mathrm{~min}^{-1}$. Low values of the effective specific consumption of LPG also confirm the high enough efficiency of the gas ICE. In this case, for the diesel engine, the effective specific consumption of diesel fuel when operated at rated capacity amounted to $g_{e, d}=238 \mathrm{~g} /(\mathrm{kW} \cdot \mathrm{h})$, and the minimum consumption is $226 \mathrm{~g} /(\mathrm{kW} \cdot \mathrm{h})$ at $n=1,800 \mathrm{~min}^{-1}$.

The coefficient of excessive air $\lambda$ slowly increases throughout the entire external speed characteristic, from 0.99 (in a zone close to the rated rotation frequency) to 1.1 (in a zone of mean and minimum rotation frequencies). Its magnitude in a zone of the rated rotation frequency is adversely affected, as well as the filling factor, by the presence of the air mixer (diffuser).

Basically, the gas ICE operates on lean mixtures, at which the total heat losses reach a minimum, which, consequently, provides maximum effective engine power.

All speed and loading operating modes of the converted gas ICE D-240-LPG with the system of power and supply of LPG to the inlet pipeline and a contactless electronic ignition system with a movable voltage distributor demonstrated steady operation.

Basic specifications of D-240-LPG in co MParison to the diesel engine D-240 are given in Table 1.

Basic specifications of the diesel engine D-240 [17] and the gas ICE, model D-240-LPG, converted on its base

\begin{tabular}{|c|c|c|}
\hline Parameter title & \multicolumn{2}{|c|}{ Parameter value } \\
\hline ICE brand & D-240 & D-240-LPG \\
\hline Type & $\begin{array}{c}\text { Four-stroke diesel engine } \\
\text { with compression ignition }\end{array}$ & $\begin{array}{l}\text { Four-stroke gas ICE } \\
\text { with spark ignition }\end{array}$ \\
\hline Mixture formation technique & $\begin{array}{l}\text { Internal (direct fuel } \\
\text { injection) }\end{array}$ & $\begin{array}{l}\text { External (supply of the } \\
\text { LPG to inlet pipeline) }\end{array}$ \\
\hline Rated power, $\mathrm{kW}$ & 59 & 57.5 \\
\hline Rotation frequency at rated power, $\min ^{-1}$ & 2,200 & 2,250 \\
\hline Maximum torque/at rotation frequency, $\mathrm{N} \cdot \mathrm{m} / \mathrm{min}^{-1}$ & $305 / 1,400$ & $304 / 1,300$ \\
\hline Rated torque margin factor, $\%$ & 19 & 22 \\
\hline Maximum rotation frequency at idling, $\mathrm{min}^{-1}$ & 2,385 & 2,250 \\
\hline Piston bore, $\mathrm{mm}$ & \multicolumn{2}{|l|}{110} \\
\hline Piston stroke, $\mathrm{mm}$ & \multicolumn{2}{|l|}{125} \\
\hline Number of cylinders & \multicolumn{2}{|l|}{4} \\
\hline Work volume, 1 & \multicolumn{2}{|c|}{4.75} \\
\hline Sequence of cylinder work & \multicolumn{2}{|c|}{$1-3-4-2$} \\
\hline Compression ratio & 16 & 9.5 \\
\hline Fuel & diesel & LPG \\
\hline
\end{tabular}

In addition, as demonstrated by the experimental study, the designed shape of the combustion chamber enabled a nondetonation operation of the gas ICE.

\section{Discussion of results of studying the conversion of the diesel engines into gas ICEs with spark ignition}

The research reported in this paper is the first stage in the development of a technology for converting the transport diesel engines into gas ICEs with spark ignition. It is envisaged that the technology should cover the diesel engines with a different number and location of cylinders, as well as the sequence of their operation. Therefore, in the first stage, the technology for converting the atmospheric diesel engines (equipped with high-pressure fuel pumps and mechanical direct-acting controllers) has been devised, which have no systems of neutralization of exhaust gases.

In addition, the new designed shape of the combustion chamber can be used for the further stages of the conversion technology.

Thus, converting the diesel engines into gas ICEs with the designed shape of the combustion chamber and the selected LPG supply and ignition systems is an effective way to reduce operating costs of $\mathrm{Vs}$, as evidenced by experimental study. Separately, it should be noted that the effective gas ICE capacity was $97 \%$ of the rated power of the diesel engine $\mathrm{D}-240$, which is especially important for converting the diesel engines of universal tractors.

The proposed technology for converting the diesel engines into gas ICEs has the advantage that it can be used in the conversion of atmospheric transport diesel engines with a different number and location of cylinders, as well as the sequence of their operation. In addition, the use of the first phase of the devised technology does not require any special costly equipment and may be applied to convert the diesel engines already in service.

At the same time, it is obvious that the applied LPG supply system does not make it possible to automatically adjust both the rotation frequency at idling and the magnitude of an LPG starting supply depen-

Table 1 ding on the temperature of the cooling fluid in an ICE. In addition, such an LPG supply system does not allow the use of three-component catalytic neutralizers to reduce the toxicity of exhaust gases.

Therefore, the further direction of this work relates to the development of a multifunctional electronic microprocessor control system for a gas ICE. The system should enable the control over such subsystems as a multipoint LPG injection by gas electromagnetic injectors; filling the cylinders with a shot of the working mixture, a contactless electronic ignition subsystem, lambda regulation of the composition of the gas-air mixture, etc.

\section{Conclusions}

1. It has been proven that the most technological technique to reduce the compression degree when converting the diesel engines D-240 into gas ICE D-240-LPG is to reduce the geometric degree of compression by increasing the volume of the combustion chamber. For gas ICEs, the unpartitioned open combustion chamber has been substantiated and designed in the form of an axisymmetric «truncated cone». 
2. Based on the standard diesel pistons for the diesel engines D-240, which have the undivided semi-enclosed CNIDI combustion chambers, the pistons were fabricated with the designed shape of the combustion chamber.

3. A special ECU Avenir Gaz has been designed and manufactured, which limits the maximum rotation frequency of a gas ICE by disabling the supply of LPG when the current magnitude of rotation frequency exceeds the maximum frequency assigned by ECU. In addition, such ECU makes it impossible to supply LPG to the gas-air mixer and inlet pipeline before the start of the gas engine, which improves the safety of its operation.

4. The gas ICE, model D-240-LPG, with forced ignition has been designed and constructed, operated on LPG, which was converted on the basis of the transport diesel engine D-240. The gas ICE is equipped with pistons with the designed shape of the combustion chamber. The compression ratio was reduced to $\varepsilon=9.5$. In addition, the engine was fitted with an LPG feeding system to the inlet pipeline and a contactless electronic ignition system with a movable voltage distributor.
5. The gas ICE D-240-LPG was tested at an electric loading bench. The results of testing the gas ICE D-240-LPG have proven that the rated power of the gas ICE-240-LPG was $97 \%$ of the rated power of the diesel engine D-240. The torque margin is $22 \%$. The effective consumption of LPG when the engine operates by external speed characteristic ranges from 4.0 to $11.3 \mathrm{~kg} / \mathrm{h}$ (or $7.5 \ldots 21.1 \mathrm{l} / \mathrm{h}$ ). The derived energy and economic parameters have shown that converting the diesel engines into gas ICEs is an effective way to reduce operating costs by diesel vehicles.

\section{Acknowledgements}

The author of this paper expresses gratitude to M. Gori, Yu. Nazarenko, K. Patlatyuk, and other employees, at the laboratory of fuel use and ecology, SE «State Road Transport Research Institute», who took part in the preparation and testing of the gas ICE.

\section{References}

1. Kovalov, S. A. (2018). Development of an electronic control system for gas-engines, converted on the basis of transport diesels to work for on liquefied petroleum gas. Internal Combustion Engines, 2, 55-61. doi: https://doi.org/10.20998/0419-8719.2018.2.09

2. Kovalov, S. (2018). Development of an electronic control system for gas-engines with spark ignition, converted on the basis of diesel engines to work for on liquefied petroleum gas. Avtoshliakhovyk Ukrayiny, 4 (256), 12-18. doi: https://doi.org/10.33868/03658392-2018-4-256-12-18

3. Avtomobil'niy spravochnik BOSCH (2000). Moscow: Izdatel'stvo «Za rulem», 896.

4. Kryshtopa, S., Panchuk, M., Dolishnii, B., Kryshtopa, L., Hnyp, M., Skalatska, O. (2018). Research into emissions of nitrogen oxides when converting the diesel engines to alternative fuels. Eastern-European Journal of Enterprise Technologies, 1 (10 (91)), 16-22. doi: https://doi.org/10.15587/1729-4061.2018.124045

5. Otto cycle. Wikipedia. Available at: https://en.wikipedia.org/wiki/Otto_cycle

6. Zakharchuk, O. V. (2014). Improvement environmental performance wheel tractor using gas fuel. Visnyk Nats. tekhn. un-tu «KhPI», 10 (1053), 27-32.

7. Miller cycle. Wikipedia. Available at: https://en.wikipedia.org/wiki/Miller_cycle

8. Mo, H., Huang, Y., Mao, X., Zhuo, B. (2016). Investigations on the Potential of Miller Cycle for Performance Improvement of Gas Engine. Global Journal of Researches in Engineering, XVI (I), 37-46.

9. Kryshtopa, S., Panchuk, M., Kozak, F., Dolishnii, B., Mykytii, I., Skalatska, O. (2018). Fuel economy raising of alternative fuel converted diesel engines. Eastern-European Journal of Enterprise Technologies, 4 (8 (94)), 6-13. doi: https://doi.org/10.15587/1729-4061.2018.139358

10. Luksho, V. A., Kozlov, A. V., Panchishny, V. I., Terenchenko, A. S. (2015). Development of a complex catalytic conversion system for internal combustion engines fueled with natural gas. Modern Applied Science. doi: https://doi.org/10.5539/mas.v9n8p237

11. Luksho, V. A., Kozlov, A. V., Terenchenko, A. S., Ter-Mkrtichian, J. G., Karpukhinn, K. E. (2015). Technical and Economic Analysis of Vehicles Pollutant Emissions Reduction Technologies. Biosciences Biotechnology Research Asia, 12 (2), 1867-1872. doi: https:// doi.org/10.13005/bbra/1852

12. Vansheydt, V. A., Ivanchenko, N. N., Kollerov, L. K. (Eds.) (1977). Dizeli. Leningrad: «Mashinostroenie», 480.

13. Abramchuk, F. I., Voronkov, A. I., Otchenashko, S. I. (2008). Analiz kamer sgoraniya, ispol'zuemyh v sovremennyh vysokooborotnyh avtomobil'nyh dizel'nyh dvigatelyah. Avtomobil'niy transport, 22, 117-122.

14. Parsadanov, I. V., Khyzhniak, V. O., Rykova, I. V. (2017). Obgruntuvannia vyboru kamery zghoriannia pry zastosuvanni katalitychnoho pokryttia na poverkhni porshnia. Dvigateli vnutrennego sgoraniya, 2, 18-21.

15. EN 589+A1:2012. Automotive fuels - LPG - Requirements and test methods.

16. Katalog «DAL'NOBOYSHCHIK». Predpriyatie «Zavod Dvigatel». Available at: http://zdvigatel.com/katalog/dalnoboyshchik

17. Regulation No. 67. Uniform provisions concerning the approval of: I. Approval of specific equipment of vehicles of category $M$ and $\mathrm{N}$ using liquefied petroleum gases in their propulsion system; II. Approval of vehicles of category $\mathrm{M}$ and $\mathrm{N}$ fitted with specific equipment for the use of liquefied petroleum gases in their propulsion system with regard to the installation of such equipment.

18. GOST 18509-88. Dizeli traktornye i kombaynovye. Metody stendovyh ispytaniy (1988). Moscow: Izd-vo standartov, 69.

19. Regulation No. 120. Uniform provisions concerning the approval of internal combustion engines to be installed in agricultural and forestry tractors and in non-road mobile machinery, with regard to the measurement of the net power, net torque and specific fuel consumption.

20. Ksenevich, I. P., Kustanovich, S. L., Stepanyuk, P. N. et. al.; Ksenevich, I. P. (Ed.) (1984). Traktory MTZ-80 and MTZ-82. Moscow: Kolos, 254

21. GOST R 52087-2003 (2003). Gazy uglevodorodnye szhizhennye toplivnye. Tehnicheskie usloviya. Moscow: Izd-vo standartov, 7. 